\title{
Speech Act of Suggestion Across Language Proficiency and Gender in Iranian Context
}

\author{
Yasser Aminifard (Corresponding author) \\ Department of English, Islamic Azad University, Dehdasht Branch, Iran \\ E-mail: yasir.amini@yahoo.com \\ Ebrahim Safaei \\ Department of English, Islamic Azad University, Shahreza Branch, Iran \\ E-mail: ebrahim_safaee@yahoo.com \\ Hamdollah Askari \\ English Teacher, Department of Education, Gachsaran, Iran \\ E-mail: hamdollahaskari@yahoo.com
}

Received: 30-03-2014

doi:10.7575/aiac.ijalel.v.3n.5p.198
Accepted: 16-05-2014

Published: 01-09-2014

\begin{abstract}
This study seeks to investigate how Iranian EFL learners employ suggestion speech act. With this aim, 105 Iranian EFL learners participated in this study. A Discourse Completion Test (DCT) was used to produce data related to the suggestion forms utilized by the participants. Percentage and Chi-square test were used to analyze the data. Research findings revealed similarities and differences between English natives and Iranian EFL learners in terms of suggestion forms produced. The findings further showed that different language proficiency level did not produce any significant differences in production of suggestion speech act. However, participants' performances considering different gender reached statistical significance. It was also found that Iranian EFL learners transferred their L1 structures in using suggestion forms.
\end{abstract}

Keywords: Suggestion speech act, Language proficiency, Gender

\section{Introduction}

Pragmatics is "the study of language from the point of view of users, especially of the choices they make, the constraints they encounter in using language in social interaction and the effects their use of language has on other participants in the act of communication" (Crystal, 2003, p. 364).Pragmatic or functional use of language, such as suggestions, invitations, requests, apologies, refusals, and agreements, are essential components of language learners' communicative competence (Hymes, 1972).

With the advent of communicative competence, it has become axiomatic that the teaching of second language words and phrases isolated from their sociocultural context may lead to pragmatic failure which may hinder communicative purposes (Rose and Kasper 2001). Similarly, Shih (2006) asserts that foreign language speakers who have enough grammatical competence but have a lack of sociolinguistic awareness may encounter communicating problems with native speakers because of their being incompetent to use sociolinguistic rules properly or interpret those words correctly. The astonished look on a native English professor's face on receiving the supposedly thanking expression "I'm ashamed" from an Iranian student suggests the importance of pragmatics in communication through language (Sharifian, 2004).

According to Searle (1976) suggestions belong to the group of directive speech acts which are those in which the speaker's purpose is to get the hearer to commit him/herself to some future course of action. As Rintell (1979) states, in a suggestion, the speaker asks the hearer to take some action which the speaker believes will benefit the hearer, even one that the speaker should desire.

Banerjee and Carrell (1988) were the first scholars to conduct research specifically designed to focus on suggestions. By employing a discourse completion test (DCT) consisting of 60 situations that elicited a suggestion, these authors compared two groups of subjects, namely those of Chinese and Malay ESL students with 12 native speakers (NSs) of American English. Results from the study were analysed both quantitatively, as far as frequency, directness and type of suggestion employed, and qualitatively, regarding the use of politeness strategies and redressive forms when suggesting. The authors found that NSs made suggestions more frequently than non-native speakers (NNSs), and the type of suggestion used depended on the directness of the situation. Particularly interesting in this early study is the fact that these authors addressed the issue of instruction by posing the question "What should we be teaching in ESL classrooms that will help students when making suggestions?" 
Jiang (2006) described the linguistic forms used to perform the speech act of suggestions in both real language and ESL textbooks. Comparisons between suggestions in two authentic settings in a corpus, professor-student interaction during office hours and student-student study groups, and six popular ESL textbooks, three old and three recent, were made to evaluate the extent to which textbook materials reflect real-life language use. Register differences between office hours and study groups demonstrate the contextual sensitivity of certain linguistic forms and the complexity of performing speech acts. Although the new generation textbooks introduce more linguistic structures for suggestions than the old generation textbooks, the discrepancies between real language use and ESL textbooks are still apparent.

Despite the myriad number of suggestions we encounter in our daily conversations, the literature is remarkably sparse with regard to studies concerned with this speech act (Fernandez Guerra \& Martinez-Flor, 2005). Therefore, the present study attempts to compare and contrast the use of suggestion forms between English natives and Iranian EFL learners. It also seeks to investigate if learners with different language proficiency levels and gender produce different suggestion forms.

\section{Research Questions}

To the above-mentioned ends, the following research questions were posed:

1. Are there any differences in the production of suggestion forms between English natives and Iranian EFL learners?

2. Is there a significant difference among learners of different proficiency levels in their use of suggestion forms?

3. Is there a significant difference between males and females in their use of suggestion forms?

\section{Methodology}

\subsection{Participants}

A number of 105 English learners from Gachsaran (a city in Kohgiluyeh and Boyer-Ahmad Province) English institutes were selected for the purpose of this study. They included 52 males and 53 females aged from 18 to 37 . They consisted of 35 intermediate, 35 upper intermediate, and 35 advanced learners. For administrative reasons, we could not give a language proficiency test to our participants. Therefore, we had to rely on proficiency levels determined by their institutes.

\subsection{Instruments}

This study used a Discourse Completion Test (DCT) to gather data about participants' use of different suggestion forms. The DCT (see the Appendix A) was adopted from Pishghadam and Sharafadini's (2011) study. It consisted of six suggestion-eliciting situations and participants were asked to respond as if they were in those situations. Although the DCT had been piloted and used previously, it was piloted again to 17 EFL learners at a level commensurate to that of the participants by the researchers to spot any possible ambiguous item.

\subsection{Procedure}

The DCT was given to the participants. They were required to finish it within 15 minutes. The necessary instructions were offered by the researchers. At data collection stage, the frequency of each suggestion form was calculated and assessed qualitatively. The findings were compared with those of Jiang (2006) in order to find out the similarities and differences between English natives and Iranian EFL learners with regard to the utilization of suggestion speech act. Also, two Chi-square tests were used to understand whether language proficiency and gender moderated participants' utilization of different suggestion forms.

To classify the suggestion forms produced by the participants, Jiang's (2006) taxonomy of suggestion speech act was used. This entailed nine suggestion forms based on their grammatical features (see Appendix B).

\section{Results and Discussion}

Due to the fact that the study was conducted in an EFL context and accessibility of English natives were not feasible, Jiang (2006)'s suggestion taxonomy, which was based on TOEFL 2000 Spoken and Written Academic Language Corpus (T2K-SWAL Corpus), was used in order to compare and contrast English natives and Iranian EFL learners in terms of their utilization of suggestion speech act.

Table 1. Frequency and Percentage of Suggestion Forms by Natives and Iranian EFL Learners

\begin{tabular}{lcccc}
\hline Suggestion forms & Natives frequency & Percentage & $\begin{array}{c}\text { Iranian EFL } \\
\text { learners frequency }\end{array}$ & Percentage \\
\hline Let's & 213 & $40.8 \%$ & 5 & $1.0 \%$ \\
Modals and semi-modals & 148 & $28.3 \%$ & 242 & $47.8 \%$ \\
Wh-questions & 34 & $6.5 \%$ & 8 & $1.6 \%$ \\
Conditionals & 18 & $3.4 \%$ & 35 & $6.9 \%$ \\
Performatives & 11 & $2.1 \%$ & 75 & $14.8 \%$ \\
Pseudo cleft structures & 13 & $2.4 \%$ & 0 & $0 \%$ \\
Extraposed to-clauses & 3 & $0.5 \%$ & 22 & $0 \%$ \\
Yes/ no questions & 0 & $0 \%$ & 119 & $4.3 \%$ \\
Imperatives & 82 & $15.7 \%$ & 0 & $23.5 \%$ \\
\hline
\end{tabular}


As table 1 shows, except for "yes/no questions" which were not attempted by natives and "pseudo cleft structures" and "extraposed to-clauses" which were not utilized by Iranian EFL learners, both groups used all types of suggestion forms, albeit with remarkably different frequencies. A quick look at table 1 reveals that "let's", with $40.8 \%$, accounts for the largest part of suggestion forms in natives' samples. The second-ranked suggestion form used by natives is "Modals and semi-modals" with $28 \%$. Following behind are "imperatives" and "wh-questions" with $15.7 \%$ and $6.5 \%$ respectively. The biggest share of suggestion form that Iranian EFL learners employed pertains to "modals and semimodals" with $47.8 \%$, followed by "imperatives" (23.5\%) and "performatives"(14.8\%). In spite of the fact that "let's" comprises significant proportion of suggestion forms (40.8\%) in natives' sample, it is the least frequent suggestion form utilized by Iranian EFL learners (1.0\%). A bar graph depicting how Iranian EFL learners employed different suggestion forms has been presented below.

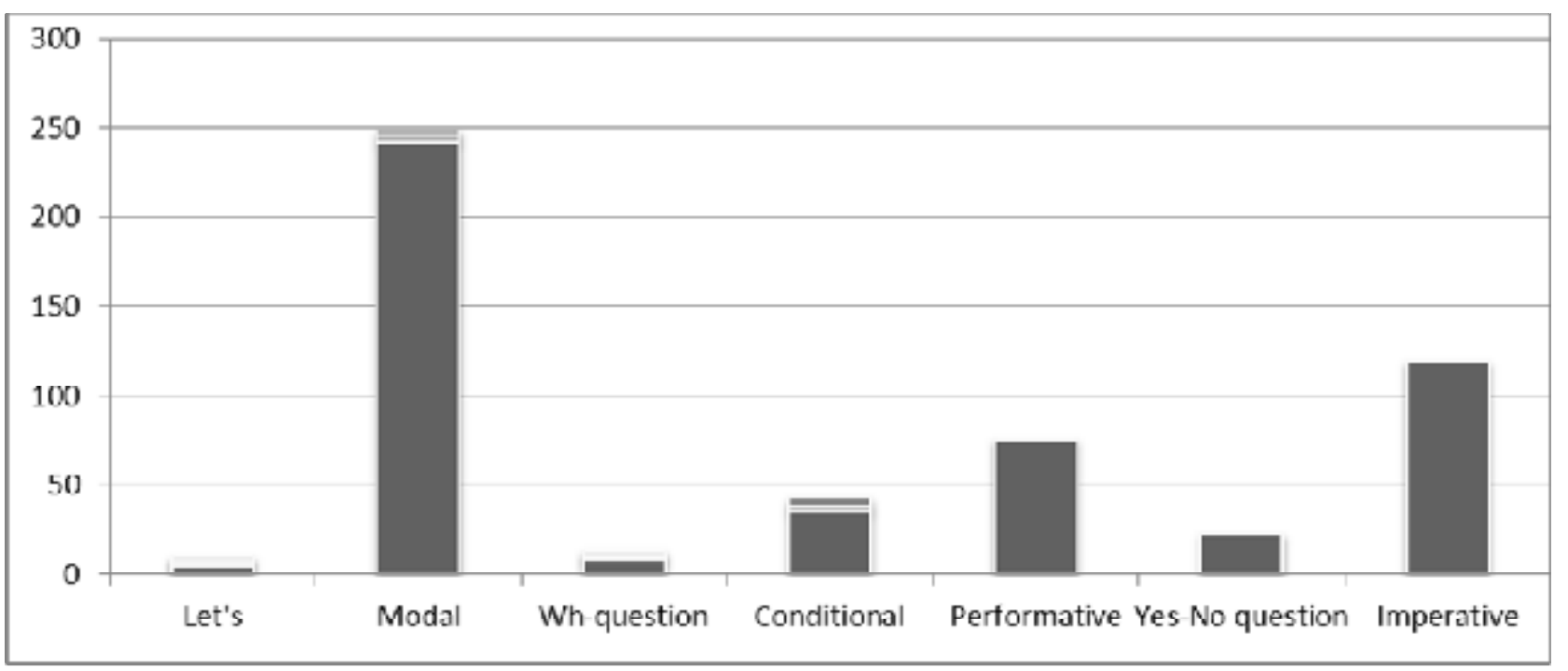

Figure 1. Bar graph showing Iranian EFL learners' utilization of different suggestion forms

With respect to the first research question, findings indicate that English natives and Iranian EFL learners revealed both similarities and variations in their use of suggestion forms. This mirrors (Pishghadam \& Sharafadini, 2011)'s study in which "modals" and "imperatives" were the most common forms between two groups. The findings of the current study are in line with those of Liu and Zhao (2007) who considered modals as one of the most frequent suggestion making forms by both natives and EFL learners. This could be ascribed to the pedagogical materials used in Iran since English textbooks teach these strategies directly. Additionally, they can be considered as universal forms which are utilized in the Persian language, which can be transferred positively (Pishghadam \& Sharafadini, 2011, p. 157).

Interestingly enough, the most conspicuous difference observed between the two groups pertains to the use of "let's" form. "Let's"... was enormously used by natives while it was hardly attempted by Iranian EFL learners. This parallels the findings of (Pishghadam \& Sharafadini, 2011); however, it is in sharp contrast with (Mahmoudi Gahrouei, 2013) who claimed that "let's..." is the most frequently used structure for making suggestions among TEFL students of Yazd University, Iran. Also, "yes/no question" was absent from natives' data whereas it was partly used by Iranian EFL learners. Liu and Zhao (2007) argue that "let's" is considered to be a more direct structure in comparison with "yes/no question" which can be used as an indirect suggestion form. Therefore, our findings are compatible with the contention of Nelson, Carson, Al Batal, and El Bakary (2002, cited in Allami \& Naeimi, 2010) that there is a preference for direct and explicit communication in American culture, while Iranians tend to use more implicit communication style.

Turning now to the second research question, a Chi-square test of independence was performed to examine the relationship between language proficiency level and utilization of suggestion forms. As seen in table 2, the analysis revealed that the relationship between these variables was not significant, $\chi^{2}(8,493)=11.50, p=.175$.In other words, Iranian EFL learners of different language proficiency levels (intermediate, upper-intermediate and advanced) showed no difference in their orientation towards using different suggestion forms.

Table 2.Chi-Square Test for the relationship between language proficiency

and utilization of suggestion forms

\begin{tabular}{llll}
\hline & Value & $d f$ & $\begin{array}{l}\text { Asymp.Sig. } \\
\text { (2-sided) }\end{array}$ \\
\hline Pearson Chi-Square & $11.508^{\mathrm{a}}$ & 8 & .175 \\
Likelihood Ratio & 12.130 & 8 & .145 \\
Linear-by-Linear & .197 & 1 & .657 \\
Association & 493 & & \\
\hline
\end{tabular}

0 cells $(.0 \%)$ have expected count less than 5 . The minimum expected count is 6.96 . 
A bar graph has been provided below to clearly show the distribution of suggestion forms across different language proficiency levels.

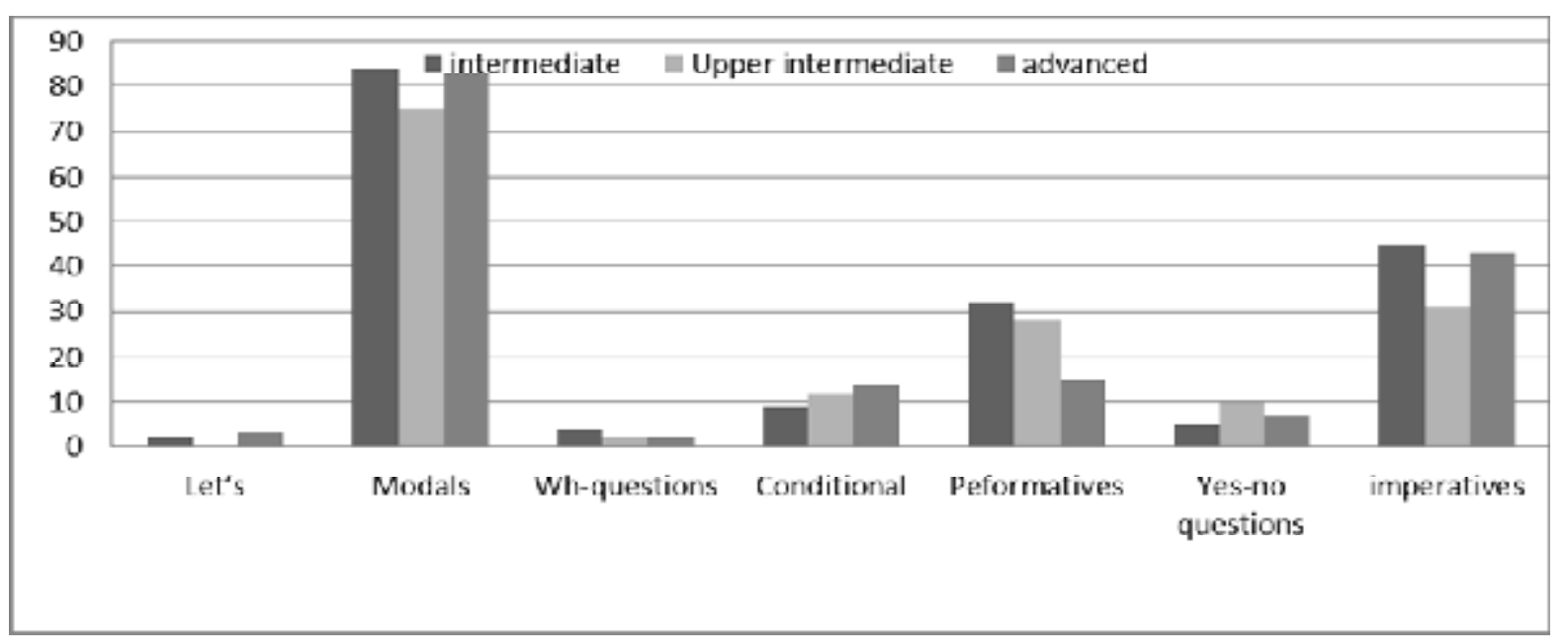

Figure 2. Bar graph showing utilization of suggestion forms across language proficiency

As shown in figure 2, all learners, irrespective of the language proficiency levels, have predominantly opted for "modals", "imperatives" and "performatives", which are among the most frequently used structures to make suggestions in Persian language. It is noticeable that all EFL learners in this study have transferred language forms from their L1. Thus, this is opposed to Allami and Naimi (2010) who reported that upper intermediate learners had the more instances of L1 samples. Our study also contradicts previous findings (Pishghadam \& Sharafadini, 2011) who asserted that upper intermediate and advanced learners had the more instances of L1 transfer since they are in the middle of process of constructing their interlanguage, and use their L1 as a linguistic resource to compensate for the existing gap in their interlanguage.

Another possible explanation for a lack of diversity in the suggestion-making data produced by the participants of this study might be the unpalatable fact that almost all the language institutes in the area where we conducted our study do not bother to administer regular placement tests before the commencement of each semester (The head of English Institutes, personal communication, October, 2012) so that their education could be beneficial down the line. For instance, "let's..." is by far the most frequently used structure for making suggestions and should be taught in ESL/EFL classes at any early stage of instruction(Jiang, 2006), but we observed that even the advanced participants had not chosen to use it much. This also might be due to the fact that teachers do not raise students' consciousness of the various suggestion forms in the textbooks and how and when to use them, an important issue that has been ubiquitously discussed in the literature on L2 pragmatics (Thomas, 1983, cited in Sum-hung Li, 2010).

With respect to the third research question, a Chi-square test of independence in table 3 revealed that there was a significant relationship between the gender and utilization of suggestion forms, $\chi^{2}(4,509)=13.85, p=.008$. Alternatively put, gender had an impact on the choice of suggestion form among the participants.

Table 3.Chi-Square Tests for the relationship between gender and utilization of suggestion forms

\begin{tabular}{llll}
\hline & Value & $d f$ & $\begin{array}{l}\text { Asymp.Sig. } \\
(2 \text {-sided })\end{array}$ \\
\hline Pearson Chi-Square & $13.855^{\mathrm{a}}$ & 4 & .008 \\
Likelihood Ratio & 14.251 & 4 & .007 \\
Linear-by-Linear & 2.820 & 1 & .093 \\
Association & 509 & & \\
\hline
\end{tabular}

a. 0 cells $(.0 \%)$ have expected count less than 5 . The minimum expected count is 9.55 .

Inspecting the individual cells in Table 4, we see that only the adjusted residuals corresponding to the "performatives" category are above the cut-off point of 2 , hence significant. That is to say, the proportion of "performatives" as a form of making suggestion is significantly different between males and females in the current study. 


\begin{tabular}{|c|c|c|c|c|c|c|c|c|}
\hline & & & & \multicolumn{4}{|c|}{ Suggestion form } & Total \\
\hline \multirow{9}{*}{ Gender } & \multirow{3}{*}{ Male } & & Modals & Conditionals & Performatives & Yes/no Qs & Imperatives & \\
\hline & & Count & 125 & 11 & 22 & 11 & 52 & 221 \\
\hline & & Expected Count & 109.8 & 15.6 & 33.9 & 9.6 & 52.1 & 221.0 \\
\hline & \multirow{3}{*}{ Female } & Adjusted Residual & 2.7 & -1.6 & $-2.9 *$ & .6 & .0 & \\
\hline & & Count & 128 & 25 & 56 & 11 & 68 & 288 \\
\hline & & Expected Count & 143.2 & 20.4 & 44.1 & 12.4 & 67.9 & 288.0 \\
\hline & \multirow{3}{*}{ Total } & Adjusted Residual & -2.7 & 1.6 & $2.9^{*}$ & -.6 & .0 & \\
\hline & & Count & 253 & 36 & 78 & 22 & 120 & 509 \\
\hline & & Expected Count & 253.0 & 36.0 & 78.0 & 22.0 & 120.0 & 509.0 \\
\hline
\end{tabular}

The following bar graph indicates how male and female participants have employed different suggestion forms.

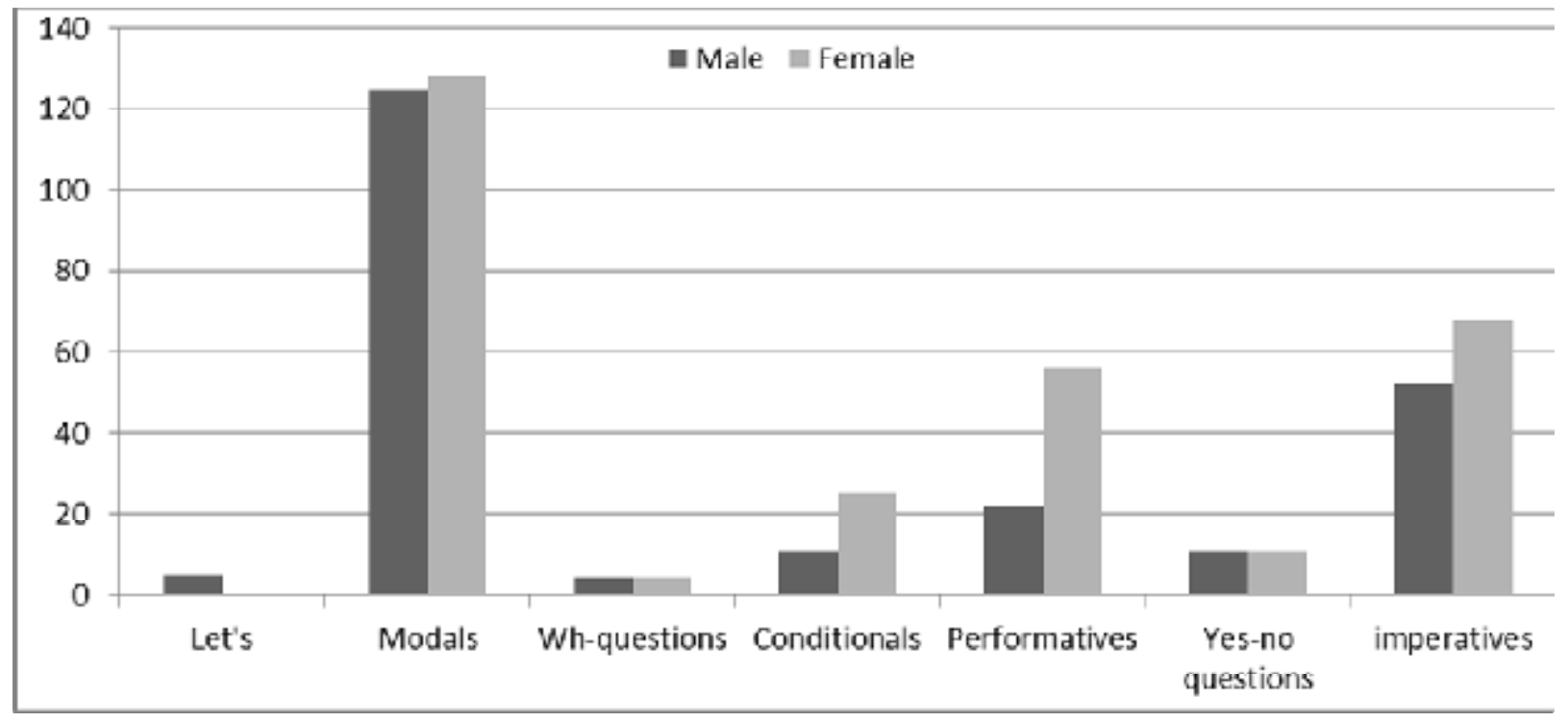

Figure 3. Bar graph showing utilization of suggestion forms across gender

As mentioned above, gender was a significant factor in the production of "performative" forms. Therefore, this finding agrees with that of other studies in which gender was a significant factor in making suggestions (Banerjee \& Carrell, 1988; Pishghadam \& Sharafadini, 2011). However, the findings of the current study do not support the previous research (Allami, 2006; Bryant Smith, 2009) who reported gender a non-significant variable in nonnatives' production of speech acts. Interestingly, the results of this study directly contradict previous findings (Pishghadam \& Sharafadini, 2011) according to which "males tend to utilize more direct strategies such as imperatives, whereas females employ more indirect suggestions like yes-no questions (p. 157)". Bearing in mind that "performatives" are among the commonly used suggestion making forms in the Persian language, it could be said that females have transferred L1 forms to make suggestions in L2.

\section{Conclusion}

It was the main purpose of the present paper to draw attention to the ways in which English natives and Iranian EFL learners employ speech act of suggestion. It has been found that the two groups showed both similarities and differences in term of choosing among the available suggestion-making forms. Additionally, the data obtained indicated that while gender was a significant factor in using "performatives" as one of suggestion-making forms, language proficiency did not prove to moderate the participants' preference for one form over another. Although Top Notch series, which are definitely a cut above old-generation English textbooks, were taught in the language institutes under investigation, the findings suggested that students' suggestion-making samples bespeak mostly their L1 structures (i.e., the Persian language). This finding corroborates the idea of Jiang (2006), who suggested that "classroom teachers need to realize the limitations of the textbooks they choose to use in their classes and make efforts to complement them with additional materials that they consider beneficial to their students. In the case of teaching pragmatics, for example, corpora of authentic spoken language will be helpful for making the connections between language forms and functions. Classroom tasks should draw more on naturally occurring conversations rather than drills and seemingly artificial dialogues. The more naturally occurring conversations will develop students' awareness of such socio-cultural issues as register differences, interlocutor relationships (boss-employee, teacher-student, between classmates or friends, etc.), and cultural preferences" (p. 51). 


\section{References}

Allami, H. (2006). A sociopragmatic analysis of griping: The case of Iranian students. The Linguistic Journal. 1(1), 5976.

Allami, H., \& Naeimi, A. (2010). A cross-linguistic study of refusals: An analysis of pragmatic competence development in Iranian EFL learners. Journal of Pragmatics, 43(1), 385-406.

Banerjee, J., Carrell, P.L., (1988). Tuck in your shirt, you squid: Suggestions in ESL. Language Learning 38, $313-364$.

Bryant Smith, J. (2009). The acquisition of pragmatic competence: Complement response strategies in learners of Spanish. A doctoral dissertation, Louisiana State University.

Crystal, D. (2003).A Dictionary of Linguistics \&Phonetics (5th edition). Maldern MA: Blackwell.

Fernandez Guerra, A., \& Martinez-flor, A. (2005). Is teaching how to suggest a good Suggestion? An empirical study based on EFL learners" accuracy and appropriateness when making suggestions. Porta Linguarum, 5, 91-108.

Jiang, X. (2006). Suggestions: What should ESL students know? System, 34(1), 36-54.

Liu, Y., \& Zhao, J. (2007).Suggestions in teacher-student conferences. Arizona Working Papers in SLA and Teaching, 14, 59-74.

LoCastro, V. (2012).Pragmatics for language educators. New York: Routledge.

Mahmoudi Gahrouei, V. (2013).A Sociopragmatic Study of Speech Act of Suggestion in Persian EFL Learners. The Iranian EFL Journal (9)1, 241-249.

Pishghadam, R., \& Sharafadini, M. (2011). Delving into Speech Act of Suggestion: A Case of Iranian EFL Learners. International Journal of Business and Social Science, 2(16), 152-160.

Rintell, E., 1979. Getting your speech act together: The pragmatic ability of second language learners. Working Papers on Bilingualism 17, 97-106.

Rose, K. R., \& Kasper, G. (Eds.). (2001). Pragmatics in language teaching. Cambridge: Cambridge University Press.

Sharifian, F. (2004). Cultural Schemas and Intercultural Communication: A study of Persian. In J. Leigh \& E. Loo (Eds.), Outer Limits: A Reader in Communication Across Cultures (pp. 119-128). CAE: Melbourne.

Shih, H. (2006). An Interlanguage Study of the Speech Act of Apology Made by EFL Learners in Taiwan.MA thesis, National Sun Yat-sen University.

Sum-hung Li, E. (2010). Making suggestions: A contrastive study of young Hong Kong and Australian students. Journal of Pragmatics, 42 (3), 598-616.

\section{Appendix A. Discourse Completion Test}

Please complete the information required:

Sex: male $\square$ female $\square$

Native language:

Nationality:

Age:

Which level are you studying? Beginner $\square$ Elementary $\square$ Intermediate $\square$ Upper intermediate $\square$ Advanced $\square$

1. You and one of your English teachers meet in a bookstore. He/she is considering buying an expensive book about English vocabulary learning. However, you have seen the book in another bookstore at a lower price. What would you suggest your teacher?

Teacher: This book contains useful points and of course it is expensive.

You:

2. Your sister/brother's friend (younger than you) would like to contact people from other countries in order to know other customs and be able to practice the English language. You think that chatting on the internet is a very good and fast way of meeting people from all over the world. What would you suggest her? Sister/brother' s friend: but I did not discover an appropriate way to contact people from other countries. You:

3. You see one of your new classmates working in the library very late in the evening. She/he is searching the Internet in order to prepare a lecture and looks very tired. What would you suggest to this classmate? Classmate: I am so tired since, I’ ve been working all day.

You: 
4. You' re at the grocery store with your neighbor. He/she is about to buy some potato chips which are on sale. You notice that the expiration date is September 2010; this is November 2011. What would you suggest him/her?

Neighbor: I need some of those potato chips on the sale, please.

You:

5. You arrive home and would understand that your father is planning to drive to a city that evening. You have just heard the weather forecast and know that six inches of snow and freezing rain are predicted for that city. What would you suggest him?

Father: I am going to drive there this evening.

You:

6. You go to the candy store and buy some delicious looking candy. You are very disappointed when you taste it because it tastes terrible. A little girl whom you don' t know comes to buy some of them. What would you suggest her?

Girl: What delicious looking candy!

You:

Thank you very much

\section{Appendix B. List of suggestion forms}

1. Let's ...

2. Modals and semi-modals

You have to. . .

You * have to. . . (* means with one word in-between.)

You need to. . .

You $*$ need to. . .

You should. . .

You shouldn't. . .

You ought to. . .

You must. . .

You can. .

You could. . .

You might. . .

You're supposed to. . .

You'd/had better. . .

3. Wh-questions

Why don't you . . ?

Why not. . .?

How about . . ?

What about ...? 


\section{Conditionals}

If I were. .

If you. . .

5. Performatives

Suggest/recommend/advise/propose

Suggestion/recommendation/advice/proposal

6. Pseudo cleft structures

What. . is. . .

All. . .is. .

One thing you could do is. . .

Another thing to keep in mind is. .

One of the most important things to remember is. . .

7. Extraposed to-clauses

It might be. . . to. . .

It might not be. . . to. . .

It is * to. . .

It never hurts/. . .won't hurt/. . wouldn't hurt to. . .

8. Yes/ no questions

Have you thought oflabout ...?

Would you consider ...?

9. Imperatives 